\title{
Hermético espacio
}

\section{Gustavo Marín}

...y dejé caer de nuevo mis párpados como el telón húmedo en la tragedia, que enjuga la catarsis de los labios en el silencio,

la penumbra y la tormenta.

La noche pernocta dentro de mi celda como una sombra clara detrás de las blancas velas, como un murmullo en el pecho trémulo que sostiene la luz de mi aliento en las estrellas.

Mi solitario recoveco

lleno de aromas y recuerdos

se abre cual nocturno vuelo de astros en mis sueños.

Y tus ojos iAy, tus ojos! son tesoros que de la sombra espero el raudal de mis lloros por los que me inunda el deseo de tu mirada en el firmamento. 
Mil mariposas nocturnas se agitan en mis entrañas;

tus ojos de ónix, perdidos en la marea celeste

son peces de azabache revoloteando en las fontanas

de la noche con perfumes de miel y de nieve.

— Cuando creímos en el infinito olvidamos que somos nada-

Por eso procuro mi existencia en el umbral

en el límite del cuerpo y el abismo

donde miro dentro y fuera de mí mismo

como un ciego palpando la oscuridad.

Conozco el hastío y el dolor que nos mantiene ahogados en el pecho cuando las nubes preñadas de tormentas en el corazón del cielo revientan en la ribera de la noche sellada por telarañas en el techo.

Pon tus ojos en la estela de mi voz

y tu voz en la estela de mis ojos

para desterrar aquel silencio atroz

que nos estremece y nos vuelve locos.

Porque no puedo mirar hacia dentro

sin gritar, sin quebrar una lágrima en el suelo.

Oh, sangre de cristal ...

Quisiera volar

lejos del claustro de la piel

donde la verdad

es un rasguño en la pared,

y la soledad

es mi única mujer.

Puedo erigir un manicomio en el silencio

como el aullido de la piedra dormida

que revienta en los oídos del desierto...

- Cuando creímos en el infinito olvidamos que somos nada- 